\title{
Equal Opportunity Law and the Construction of Internal Labor Markets
}

\section{Citation}

Dobbin, Frank, John R. Sutton, John W. Meyer, and W. Richard Scott. 1993. Equal opportunity law and the construction of internal labor markets. American Journal of Sociology 99(2): 396-427. Reprinted in W.R. Scott and J.W. Meyer, eds., Institutional Environments and Organizations. Thousand Oaks, Calif.: Sage.

\section{Published Version}

http://dx.doi.org/10.1086/230269

\section{Permanent link}

http://nrs.harvard.edu/urn-3:HUL.InstRepos:3310575

\section{Terms of Use}

This article was downloaded from Harvard University's DASH repository, and is made available under the terms and conditions applicable to Other Posted Material, as set forth at http:// nrs.harvard.edu/urn-3:HUL.InstRepos:dash.current.terms-of-use\#LAA

\section{Share Your Story}

The Harvard community has made this article openly available.

Please share how this access benefits you. Submit a story.

\section{Accessibility}




\title{
Equal Opportunity Law and the Construction of Internal Labor Markets
}

\author{
Frank Dobbin; John R. Sutton; John W. Meyer; Richard Scott
}

The American Journal of Sociology, Vol. 99, No. 2. (Sep., 1993), pp. 396-427.

Stable URL:

http://links.jstor.org/sici?sici=0002-9602\%28199309\%2999\%3A2\%3C396\%3AEOLATC\%3E2.0.CO\%3B2-9

The American Journal of Sociology is currently published by The University of Chicago Press.

Your use of the JSTOR archive indicates your acceptance of JSTOR's Terms and Conditions of Use, available at

http://www.jstor.org/about/terms.html. JSTOR's Terms and Conditions of Use provides, in part, that unless you have obtained prior permission, you may not download an entire issue of a journal or multiple copies of articles, and you may use content in the JSTOR archive only for your personal, non-commercial use.

Please contact the publisher regarding any further use of this work. Publisher contact information may be obtained at http://www.jstor.org/journals/ucpress.html.

Each copy of any part of a JSTOR transmission must contain the same copyright notice that appears on the screen or printed page of such transmission.

JSTOR is an independent not-for-profit organization dedicated to and preserving a digital archive of scholarly journals. For more information regarding JSTOR, please contact support@jstor.org. 


\title{
Equal Opportunity Law and the Construction of Internal Labor Markets ${ }^{1}$
}

\author{
Frank Dobbin \\ Princeton University
}

John R. Sutton

University of California, Santa Barbara

John W. Meyer and W. Richard Scott

Stanford University

\begin{abstract}
Internal labor markets have been explained with efficiency and control arguments; however, retrospective event-history data from 279 organizations suggest that federal Equal Employment Opportunity (EEO) law was the force behind the spread of formal promotion mechanisms after 1964. The findings highlight the way in which American public policy, with its broad outcome-oriented guidelines for organizations, stimulates managers to experiment with compliance mechanisms with an eye to judicial sanction. In response to EEO legislation and case law, personnel managers devised and diffused employment practices that treat all classes of workers as ambitious and achievement oriented in the process of formalizing and rationalizing promotion decisions.
\end{abstract}

\section{INTRODUCTION}

Do the policies of America's notoriously "weak" federal state have any effect on organizational practices at all? Until recently organizational theorists seemed to agree that they only affected management behavior at the margins. Lately, that belief has come under scrutiny. Organizational analysts have come to the conclusion that common management practices do not arise through spontaneous combustion in thousands of different

${ }^{1}$ The research reported here was supported by the National Science Foundation (grant SES-8511250). We are grateful to Lauren Edelman and Ann Swidler for their participation in an earlier study that this project draws upon, and to Keith Allum, Jessica Torres, and Roberta Stich for helping us to conduct the survey and code the data. Paul Burstein, Yinon Cohen, Paul DiMaggio, Lauren Edelman, Matthijs Kalmijn, Peter Marsden, Stephen Mezias, Debra Minkoff, and John Skrentny provided useful suggestions. Correspondence may be directed to Frank Dobbin, Department of Sociology, Princeton University, 2-N-2 Green Hall, Princeton, New Jersey 08544-1010.

(C) 1993 by The University of Chicago. All rights reserved.

0002-9602/94/9903-0004\$01.50 
locations at once; rather they are socially constructed by networks of managers who are attentive to signals and incentives that emanate from the state, the legal system, and the wider political culture. Many practices we think of as motivated by strict efficiency concerns, such as merger and acquisition strategies, can be traced to an iterative process in which the state creates broad rules about corporate behavior and then organizations experiment to find practical strategies that will be acceptable to the courts (Fligstein 1990; Edelman 1992). In this article we chart the roles of equal employment opportunity law, personnel managers, and the courts in designating internal labor market (ILM) practices as appropriate means to the prevention of discrimination and to the efficient allocation of human capital. We review arguments made by rationalist organizations theorists and labor economists about why managers adopt ILM practices, and we show that, net of the variables those theorists point to, changes in EEO law have a marked effect on the incidence of these practices.

Before the 1930s, firms were organized to recruit almost exclusively from the external labor market, and they seldom promoted current employees to fill open positions (Jacoby 1985). Public organizations were more likely to use civil service practices that facilitated internal promotion, but civil service systems were far from universal in the public sector (DiPrete 1989; Tolbert and Zucker 1983). By the 1950s internal promotion systems had become widespread: William Whyte's The Organizations Man (1956) characterized them as emblematic of the modern organization and as the driving force behind corporate careerism. Under what circumstances do organizations adopt practices that facilitate the recruitment of existing employees to fill open positions? Below we use eventhistory techniques to analyze the adoption of six bureaucratic personnel practices that are integral to ILMs: formal job descriptions, performance evaluations, salary classification systems, job ladders, employment tests, and promotion tests. Our focus is not on whether firms practice internal promotion, but on whether they employ the bureaucratic rules associated with ILMs (Stark 1986, p. 493).

\section{PERSPECTIVES ON INTERNAL LABOR MARKETS}

Since the time of Max Weber (1978, p. 957), who saw career-oriented employment structures as part and parcel of bureaucracy, most analysts have made efficiency arguments to explain formal internal promotion systems. Recent rationalist works suggest that increases in organizational size lead to differentiation and specialization and, in turn, to the formalization of a wide range of activities, including personnel activities (Blau et al. 1976). Blau and Schoenherr (1971) and Pugh, Hickson, and Hinings (1969) have found that, indeed, large organizations are more likely to 
adopt personnel practices, such as formal job descriptions, that are associated with ILMs. Large organizations have also been found to offer better promotion opportunities than small ones (Phelps Brown 1977), which may suggest that they are more likely to use internal promotion schemes.

Peter Doeringer and Michael Piore's (1971) seminal Internal Labor Markets and Manpower Analysis sought to reconcile the existence of ILMs with neoclassical economic views-which suggest that free competition in open labor markets is ultimately efficient-by arguing that ILMs help companies to retain firm-specific skills and reward workers for developing such skills. In technologically advanced sectors, employees must learn complex skills on the job and employers use the carrot of promotions to persuade such workers to stay with the firm. Oliver Williamson's (1975) transaction costs approach offers a similar hypothesis: employers with complex technologies will pursue long-term employment arrangements in order to escape the high cost of training new workers. These arguments suggest that ILMs should be found in technologically advanced industries that depend on firm-specific skills. Neo-Marxists emphasize control over the work force rather than efficiency, but they predict that ILMs will appear in these very sectors (Edwards 1979; Gordon, Edwards, and Reich 1982). These approaches also suggest that laborintensive, service-sector industries that do not utilize firm-specific skills will be unlikely to adopt ILMs. ${ }^{2}$

Another sort of efficiency argument suggests that firms will adopt formal ILM practices in response to competitive pressures from the external labor market. When internal promotion schemes are provided by competing organizations, managers will implement them to retain existing workers and attract new ones. This suggests that the prevalence, or density, of a practice in the sample should be positively related to the likelihood of adoption.

By contrast, conflict approaches point to struggles over the terms of employment between personnel professionals and labor leaders. In a cross-sectional analysis of data collected in the late 1960s, Pfeffer and Cohen (1984; Cohen and Pfeffer 1986) find that factors associated with efficiency do not predict ILMs. Instead, ILMs depend on the relative power of personnel managers, who favor ILMs because they expand personnel activities, and unions, who oppose ILMs because they under-

\footnotetext{
${ }^{2}$ We also operationalized labor economists' arguments with a number of sector-level variables that are thought to tap firm-specific skills and labor-market characteristics: capital-labor ratio (capital expenditures $\div$ labor expenditures) and percentages of managerial employees, professional employees, black employees, and female employees. These factors showed no effects in multivariate models, but we hesitate to draw conclusions because they are measured at the sectoral level.
} 
mine union authority over jobs. The presence of a personnel department should increase the likelihood an organization will install ILM practices; the presence of a union should decrease the likelihood.

\section{EQUAL EMPLOYMENT LAW AND INTERNAL LABOR MARKETS}

We stress wider institutional forces that operate through public policy, the courts, and personnel professionals. In recent decades American law and public institutions have elaborated rights for diverse categories of individuals and have developed standard organizational models for incorporating such rights. We see these general institutional processes as creating widespread adaptations in all sorts of organizations over time.

Strict, ahistorical, efficiency explanations of the proliferation of ILMs have been challenged by recent historical studies that examine the role of such institutional factors in the changing construction of efficiency. In 1935 the Wagner Act legitimized industrial unions and established mechanisms to protect union organizing efforts. In response employers began to hire personnel professionals who advocated ILM mechanisms to counter unionism (Jacoby 1985). During World War II the War Production Board, the War Labor Board, and the War Manpower Commission exercised controls over labor mobility, employment practices, and wages in order to ensure stability in sectors that contributed to the war effort. Personnel professionals responded by promoting ILM mechanisms to facilitate federal accountability and rationalize the use of human resources (Baron, Dobbin, and Jennings 1986). Michael Burawoy (1985, p. 142) offers a slightly different argument about the role of federal policy: the Wagner Act (1935), the National War Labor Board (1942-46), and the Taft-Hartley Act (1947) narrowed the scope of union bargaining, which led unions to guard member prerogatives by pushing for formal rules governing wage rates, job duties, promotions, and seniority. Such rules became key to ILMs. Data from the 1930s and 1940s support these arguments and show that ahistorical efficiency arguments poorly predict where ILM practices will appear (Baron et al. 1986). We find that in more recent years, public policy changes associated with civil rights and equal employment opportunity have had a similarly profound impact on the growth of the personnel function (Kochan and Cappelli 1984, p. 146).

Broadly speaking, we believe the institutional forces-in the polity, the legal system, and personnel doctrine-that supported ILM mechanisms between the 1960s and the 1980s reflect a general expansion in the social construction of the individual (Thomas et al. 1987). This expanded conception of the individual-embodied in public concern and legislation about the status of women, minorities, the handicapped, and disadvantaged groups generally - contrasts distinctly with previous organizational 
constructions of the individual. In particular, the creation of formal ILM mechanisms for all categories of employees symbolically transformed people who were traditionally disadvantaged into ambitious, occupationally mobile individuals. Thus ambition and self-actualization came to be represented as characteristics of all individuals, not just white males.

This new managerial conception of worker/individual was distinctly different from the conceptions Bendix (1956), and others, charted in early management practices. At the turn of the century the Darwinist "drive system" suggested that human motivation was a matter of short-term reward and punishment (Slichter 1919). Later Taylor's (1911) rationalist logic made it the duty of managers to optimize the match between employee and job through testing and training: "The worker came to be viewed as an embodiment of aptitudes" (Bendix 1956, p. 308). The labor strife of the 1910s and 1920s led to a paternalistic managerial strategy, based on welfare work and on company unions, that represented the worker as capable of devotion to the organization that could win his heart and mind with benevolence (Brandes 1976). The subsequent growth of unions led to the institutionalization of a new and highly contractual "industrial relations" regime by the end of the 1940s, in which motivation came to depend on the long-range incentives embodied by seniority practices (Edwards 1979; Baron et al. 1986; Burawoy 1985).

Between the mid-1960s and the early 1980s, public policy, case law, and prevailing personnel ideology emphasized employment practices that carried a new vision of the individual and a new logic of human motivation. The personnel practices that symbolized the employee as motivated by reward and punishment (the drive system), as a self-interested cog in the wheel of production with a limited capacity to learn (Taylorism), as a malleable political entity (welfare work), or as member of an oppositional interest group whose actions demanded legal restraint (the industrial relations approach), gave way to practices that represent the individual as self-actualizing, future directed, and psychologically complex (Cole 1989). Some trends in employment practices were conspicuously oriented to this conception of the individual and individual rights. Organization development (OD) programs offered a management approach based firmly in psychology (Kochan and Cappelli 1984, p. 150). Sexual harassment policies aimed to protect the physical and psychological integrity of the employee. Employment-at-will clauses were designed to protect firms from employee claims to a newly articulated right to life-long employment (Sutton et al. in press). The quality-of-work-life movement promoted collective decision making, in part to improve employee morale, and advocated the "enrichment," "enlargement," or "humanization" of jobs by reversing the trend toward job simplification (Cole 1989). In this article we show that even ILM mechanisms diffused in response 
to the elaboration of this new logic. In particular, organizations installed formal ILM mechanisms to protect the rights of all classes of employees to self-actualizing, career-oriented employment, in response to shifts in the legal environment. Those legal changes led managers to view formal hiring and promotion practices not merely as means to promote equity, but as means to promote efficiency by depersonalizing decisions about the use of human resources and thereby (a) matching employees with jobs based on their abilities rather than on ascribed characteristics and (b) creating incentives for all classes of employees to excel.

\section{The Transformation of the Legal Environment}

Because America's "weak" federal state seldom dictates behavior to private actors-even corporate actors-analysts have tended to assume that it has little effect on the institutions of civil society (Hamilton and Sutton 1989). While the federal government rarely mandates the use of particular organizational practices, public policies frequently lead to clear models of organizational compliance. Federal law typically establishes broad guidelines for behavior, and corporate actors respond by designing practical compliance strategies that are in turn reviewed by courts and administrative agencies. Once approved, organizationally devised solutions act as prescriptions for legal compliance (Hamilton and Sutton 1989; Edelman 1992; Abzug and Mezias 1993). For instance, Neil Fligstein (1990) shows that organizations responded to antimonopoly policies by experimenting with vertical integration and diversification and that the courts then approved these solutions. While the creation of compliance mechanisms is iterative and haphazard in the United States, the mechanisms that emerge from this process become powerful institutional models, not unlike the solutions directly mandated by "strong" states (Meyer and Scott 1983). We suggest that the effects of U.S. policy on organizations are interesting precisely because compliance mechanisms are often worked out between organizations and the state.

In support of our hypotheses outlining the salience of the legal environment, cross-national studies suggest that nation-state characteristics are excellent predictors of organizational employment practices, whereas neoclassical economic variables have little predictive power. In a study of 12 matched companies in Germany and France, Maurice, Sellier, and Silvestre (1984) show that size, product, and technology explain little about how job hierarchies will be structured; instead, national historical differences explain much of the variance (see also Dore 1973; Lincoln and Kalleberg 1985; Maurice, Sorge, and Warner 1980).

We will argue that equal employment opportunity law led organizations to formalize promotion mechanisms to undermine managerial dis- 
crimination. How do we know that organizations did not simply adopt these measures in response to the civil rights and womens' movements? Of course these movements were important, but their broad effects do not explain the fact that organizational antidiscrimination policies converged on a set of personnel practices that were isomorphic with the procedurally oriented, quasi-judicial administrative configuration of the federal government-formal, merit-based, employment and promotion conventions complete with an internal system of grievance adjudication (see Scott and Meyer 1987). Once sanctioned by the courts, this approach eclipsed all competing strategies for redressing discrimination. It is clear that, even if social movements encouraged organizations to end discrimination, public policy shaped the particular approach organizations would embrace.

Equal employment opportunity law.-We hypothesize that two major changes in the legal environment increased the popularity of internal labor market mechanisms. First, the passage of the Civil Rights Act of 1964 prompted employers to experiment with various antidiscrimination approaches, including (1) formal hiring and promotion procedures to depersonalize employment decisions, (2) sophisticated employment and promotion tests to create objective selection criteria, and (3) numerical quotas for the employment of disadvantaged groups. Second, in the early 1970s legislative changes and court decisions required more employers to be attentive to the issue of discrimination, but discouraged the testing and quota solutions while reinforcing the ILM strategy. More generally, because ILM procedures operate on a classificatory logic in which certain categories of employees are afforded specified protections against firing and promises of consideration for promotion (Stark 1986, p. 494), they were particularly well suited to protecting rights for new classifications based on gender and minority status.

Title VII of the Civil Rights Act of 1964 made it illegal for employers with 100 or more employees to discriminate on the basis of race, color, religion, sex, or national origin. These protections were extended to persons between the ages of 40 and 65 in 1967 and to the physically and mentally impaired in 1973 (Farley 1979, p. 12). The new Equal Employment Opportunity Commission (EEOC) was charged with overseeing Title VII of the act. In September 1965 President Johnson issued Executive Order (EO) 11246, which required federal agencies as well as major federal contractors and subcontractors, and unions covering employees who work for them, to take what came to be called "affirmative action" to redress inequality. Employers associated with contracts of over $\$ 10,000$ were required to practice affirmative action, and those associated with contracts over $\$ 50,000$ were required to write affirmative action plans. Executive Order 11246 was to be enforced by the Department of 
Labor's Office of Federal Contract Compliance (OFCC), later named the OFCC Programs (OFCCP; see Burstein 1985; Edelman 1990). While federal enforcement was notoriously weak during this period (Ashenfelter and Heckmann 1976, p. 46), the threat of private litigation compelled corporate actors to be attentive to the law. Thus many organizations responded to Title VII and EO 11246 by designating affirmative action officers, and establishing affirmative action offices, between 1964 and 1970 (Edelman 1990).

In the early 1970s several judicial and administrative clarifications of EEO compliance criteria discouraged the use of tests and quotas and encouraged the adoption of formal ILM mechanisms. First, in Griggs $v$. Duke Power Company (401 U.S. 424, 1971), the Supreme Court outlawed employment tests that were not demonstrably related to the work to be performed if those tests had the effect of excluding blacks. In ruling that employment tests must be relevant to job tasks the Supreme Court spurred firms to specify job prerequisites, in written job descriptions, and discouraged them from using general employment tests. In 1974 EEOC guidelines explicitly stated that education, experience, and test scores could not be used as selection criteria unless they could be shown to be related to job performance (U.S. Equal Employment Opportunity Commission 1974, pp. 35-40). Few employers were able to convince the courts that their tests could predict job performance (Burstein and Pitchford 1990) and, as a result, many ceased using testing to achieve EEO goals.

Second, in the early 1970s, discrimination and reverse-discrimination suits increased in number. Between 1965 and 1970 only three reversediscrimination suits reached appellate courts, yet in the next six-year period 24 such suits were heard (Burstein 1990; Burstein and Monaghan 1986, p. 380). These suits made employers reluctant to follow compliance strategies, such as quotas, that explicitly gave an edge to disadvantaged groups. Voluntary quotas (i.e., those not mandated by courts) had never been the favored EEO compliance strategy (Burstein 1985), and now several well-publicized judgments found them to be illegal (Leonard 1985). In addition, the General Accounting Office's interpretation of the Equal Employment Opportunity Act of 1972 rejected the use of quotas in the federal Civil Service on the grounds that quotas would undermine the merit system (DiPrete 1989, p. 199). This interpretation caused both public and private employers to retreat from voluntary quotas and to expand the formalization of hiring and promotion.

Third, in December 1971 the OFCCP issued Revised Order 4, which set out specific affirmative action guidelines for federal contractors. The order required federal contractors to file annual EEO reports detailing employment in each job category by gender, race, and ethnicity. The 
order also called for affirmative action plans to identify areas of minority and female "underutilization," to develop numerical goals and timetables for enlarging job opportunities in those areas, and to specify mechanisms for evaluating program effectiveness (Leonard 1985).

Fourth, the 1972 Equal Employment Opportunity Act gave the EEOC the authority to bring suit in federal court under Title VII; the act also extended Title VII coverage to private employers with 15 or more employees, to educational institutions, and to state and local governments. This legislation simultaneously expanded the scope of federal EEO law and strengthened the capacity for active enforcement. Finally, the EEOC's 1974 guidebook for employers, Affirmative Action and Equal Employment, suggested that employers could avoid litigation by formalizing hiring and promotion procedures and expanding personnel record keeping so that they would be able to prove that they did not discriminate (Benokraitis and Feagin 1977). ${ }^{3}$

\section{Personnel Professionals}

Personnel professionals played a central role in constructing formal ILM practices as EEO compliance, mechanisms. Personnel departments typically implement and administer ILMs, and they have promoted ILMs to serve a series of management problems since early in this century (Jacoby 1984). We argue that personnel departments provided the path through which ILM mechanisms diffused in the years after the Civil Rights Act.

Personnel professionals responded to the ambiguity of the 1964 legislation by developing the three principal antidiscrimination strategies we have discussed: quota systems, tests designed to objectively evaluate the qualifications of job candidates, and rules to formalize hiring and promotion. The personnel and business management journals published articles advocating all three strategies between the mid-1960s and mid-1970s (e.g., Bell 1971; Bassford 1974). Personnel managers also came to extol affirmative action-related formalization as a way to rationalize personnel allocation: open bidding for jobs would undermine favoritism and periodic, written, performance evaluations would encourage promotions based on objective criteria (Harvard Law Review 1989, p. 669). Personnel managers sold their bosses on formal evaluation and promotion systems

\footnotetext{
${ }^{3}$ The report argued that if an EEO survey shows that women and minorities are not employed in an organization "at all levels in reasonable relation to their presence in the population and the labor force, the burden of proof is on . . . [the employer] to show that this is not the result of discrimination, however inadvertent" (Farley 1979, p. vi).
} 
with two arguments: these systems thwarted discrimination and, at the same time, rationalized the allocation of human resources. Their rhetoric coupled the ideas of equity and efficiency.

Job descriptions, performance evaluations, and salary classification.In the early 1970s, in response to the OFCCP's Revised Order 4 and the 1972 expansion of the EEOC's authority, the major practitioner journals began publishing articles that promoted a specific set of ILM practices to improve federal accountability and to redress discrimination. For instance, in 1974 the Harvard Business Review published "Make Your Equal Opportunity Program Court-Proof," which emphasized "the need for positive action against the risk of prolonged and serious litigation or crippling financial judgments." It specifically encouraged firms to establish nondiscriminatory job descriptions and salary classification systems and to "ensure that prescribed qualifications and pay scales can be justified on business grounds and that inadvertent barriers have not been erected against women and minorities" (Chayes 1974, p. 81; see also Kochan and Cappelli 1984, p. 147). In the same year, the journal Personnel published "A Total Approach to EEO Compliance" (Giblin and Ornati 1974), which argued that affirmative action programs must begin with a census of minority and women employees in each department and within each major job classification-which required having a salary classification system in place-and encouraged employers to implement periodic performance evaluations for all categories of employees to make all employees eligible for promotion. Written performance evaluations were also thought to be essential to the successful defense of discrimination suits involving promotions. In brief, the personnel journals promoted salary classification systems, job descriptions, and formal performance evaluations as EEO compliance mechanisms. ${ }^{4}$ These articles noted that salary classification systems, and expanded record keeping in the areas of hiring and promotion, were now virtually mandatory for federal contractors who were required to file annual EEO reports. Evidence that federal contractors expanded black male employment in response to federal oversight (Ashenfelter and Heckmann 1976; Leonard 1984b) leads us to predict that these contractors were also likely to adopt ILM mechanisms.

Many of these articles treated EEO law as an opportunity to increase the efficiency of personnel decisions. Executives soon recognized that by

\footnotetext{
${ }^{4}$ One article in the Harvard Business Review not only advocated performance evaluations, but recommended separate performance evaluations to assess managers' affirmative action performance (Purcell 1974).
} 
requiring middle managers to justify hiring and promotion decisions, they could undermine favoritism and ensure that jobs would be filled by the best-qualified applicants. As Robert J. Samuelson argued in 1984, "Many firms have overhauled personnel policies. . . Promotions are less informal. When positions become open, they are posted so anyone (not just the boss's favorite) can apply. Formal evaluations have been strengthened so that, when a manager selects one candidate over another . . . there are objective criteria" (quoted in Harvard Law Review 1989, p. 669). By 1979 some two-thirds of top corporate executives favored government efforts to increase female and minority participation in the labor force, and a decade later the Harvard Law Review (1989) argued that managerial support for EEO had become widespread because EEO was seen as a force promoting rational personnel practices. Alternative economic analyses reinforce this view by suggesting that EEO encourages employers to match employees with jobs on the basis of their abilities rather than on the basis of irrelevant ascribed characteristics (Lundberg 1991; Donohue 1986). Thus while neoclassical economists argued that antidiscrimination laws were inefficient because they disrupted market mechanisms and unnecessary because discriminatory practices would eventually die under the weight of their own inefficiency (Becker 1971; Friedman 1962), business executives came to see EEO as a source of increased efficiency.

Job ladders, testing, and quotas. - By contrast, personnel journals suggested that formal job ladders, testing, and quota schemes could lead to problems with the EEOC and OFCCP. Formal job ladders had not been part of any of the three main EEO compliance strategies devised in the 1960s, and in the 1970s they were found to produce unnecessary barriers to advancement by making only certain groups of employees eligible for promotion. Giblin and Ornati counseled that firms should examine whether their promotion ladders "create unwarranted restrictions to minority mobility" and, in particular, whether "women or minorities are concentrated in certain jobs outside any line of progression or in jobs that dead-end" (1974, p. 40). DiPrete (1989, p. 197) argues that the problem with job ladders was quite simple: most organizations had different, discontinuous, upper- and lower-tier job ladders. Employees in the lower tier, frequently dominated by women and minorities, were generally ineligible for promotion to upper-tier jobs even if they held the necessary educational qualifications (see also Halle 1984). Federal agencies responded to EEO legislation by creating bridges between job ladders in different tiers (DiPrete 1989), but the personnel journals urged private employers to switch to open bidding systems that allowed any employee to bid for a vacant job-such systems had already substituted for formal 
job ladders in several industries (Burawoy 1985, p. 133). ${ }^{5}$ Thus after about 1973 job ladders were incorporated into some government EEO programs, but were less likely to be used in private-sector programs.

A number of personnel administrators initially believed that employment and promotion testing could solve their EEO problems. Since the time of Frederick Taylor, testing had been viewed as a way to ensure that workers would be allocated to "the highest class of jobs" that they were capable of performing, thereby maximizing both their own rewards and their utility to the organization (Bendix 1956, p. 279; Taylor 1911). Personnel managers reacted to the 1971 Griggs decision, which required them to demonstrate the relevance of tests, in two ways: some saw this ruling as a chance to expand their departments by developing more sophisticated tests that would predict job performance and stand up to EEOC guidelines (Campbell 1973; Slevin 1973; Gavin and Toole 1973; Gorham 1972; National Civil Service League 1973), while others advocated the abandonment of testing. The second camp came to prevail. A study conducted in 1973 and reported in Personnel found that $15.1 \%$ of sampled firms had already abandoned employment tests in reaction to the Griggs decision (Peterson 1974). ${ }^{6}$ Similarly, in our sample, $15 \%$ of the organizations using employment tests abandoned them during the period under study, and $11 \%$ of the organizations using promotion tests abandoned them. By contrast, no other practice was abandoned by more than $2 \%$ of the organizations using it.

The reverse-discrimination suits of the early 1970s led personnel managers to repudiate schemes, such as quotas, that explicitly advantaged protected groups. While court orders and consent decrees had required some companies to conform to specific black-white or female-male hiring ratios, the voluntary establishment of quotas had led to a number of legal fights (Harvard Law Review 1989; Burstein and Monaghan 1986; Leonard 1984a). By 1974 personnel experts were advising their colleagues that voluntary quotas could "render them liable to legal attack" (Chayes 1974, p. 87). In 1978 the widely publicized Bakke case led personnel managers who had not yet done so to excise the word "quota" from their personnel guidelines.

\footnotetext{
${ }^{5}$ A 1973 how-to article on affirmative action for women thus advocated the "institution of a method of job posting so that all employees are aware of vacancies as they occur and that promotion into these vacancies is based on qualifications, not sex" or prior position (Slevin 1973, p. 30).

${ }^{6}$ Small firms were most likely to abandon testing, in part because they could not produce sufficient data to demonstrate that tests predicted job performance (Walsh and Hess 1974).
} 
Finally, public and nonprofit organizations were most susceptible to these trends because these organizations $(a)$ depend on public opinion for legitimacy and resources and $(b)$ are subject to evaluation on the basis of their use of up-to-date procedures and structures because they cannot, in most cases, be judged on the basis of profitability (Zucker 1983; Meyer and Scott 1983; Scott 1987; Meyer and Rowan 1977). Other studies (e.g., Dobbin et al. 1988) have shown such organizations to be most likely to install formal affirmative action offices and procedures. To the extent that organizations adopt ILM mechanisms to symbolize their commitment to equality, rather than to retain firm-specific skills as labor economists suggest, we should find that the likelihood of adoption is highest among public and nonprofit organizations, rather than among technically complex organizations.

In sum, we suggest hypotheses about the spread of ILM mechanisms that challenge traditional arguments. First, whereas neoclassical and rationalist arguments treat separate ILM practices as integral parts of a whole, and predict incremental increases in their popularity as firm size and complexity increase, our arguments suggest that EEO law should affect adoption of these practices differently and that two broad shifts in the legal environment should produce dramatic, stepwise changes in the likelihood of adoption. The personnel profession came to reject two early solutions to employment discrimination, testing and quotas, in reaction to case law. As a result, the likelihood of adopting tests should increase in the period between 1964 and about 1973, but should not increase thereafter. After 1964, personnel managers began using job descriptions, performance evaluations, and salary classification systems to codify and depersonalize employment and promotion decisions. When case law reinforced these solutions in the early 1970s, personnel professionals pursued them with new vigor; thus adoption should rise after 1964 and again in the early 1970s. Initially personnel managers saw no EEO benefits in the formal job ladders that had traditionally been part of ILMs, but because job ladders were included in government EEO programs in the early 1970s, we expect their incidence to rise from 1973. Second, personnel professionals and affirmative action officers helped to develop and diffuse these compliance strategies, both individually and through their professional associations. Thus organizations with personnel departments and affirmative action offices should be susceptible to adoption. Third, public policy required federal contractors and some other organizations to file annual EEO reports. Such organizations should be likely to adopt ILM mechanisms. Fourth, public sector and nonprofit organizations have been especially attentive to personnel procedures that confer legitimacy, and we expect they will prove susceptible to the adoption of ILM mechanisms. 


\section{DATA AND METHODS}

The Sample

We selected a stratified random sample of public, for-profit, and nonprofit organizations in 1985-86, collecting retrospective data from 279 organizations on the history of their personnel practices. We generated the sample in three states-California, New Jersey, and Virginia-that have varying legal environments (Edelman et al. 1990; Sutton et al. 1994). We concentrated on a limited number of sectors, which represent different parts of the economy, so that we would be able to examine arguments about sectoral effects. In each state we selected an equal number of organizations from each of 13 sectors.

The difficulties associated with sampling organizations have been well documented (Kalleberg et al. 1990). We chose the most complete published list of organizations available for each sector. Our source for firms in publishing, banking, chemicals, machinery, electrical manufacturing, retail trade, and transportation was Dun's Million Dollar Directory, which lists all publicly traded firms with assets of at least $\$ 500,000$. We sampled hospitals from the directory of the American Hospital Association (1983) and nonprofits from the Encyclopedia of Associations (1985). To sample organizations in the public sector we used commercial telephone directories as well as official state and federal government directories. We sampled randomly from each source. We had only four criteria for inclusion in the study: that the organization was currently operating, that it was located in one of the three states selected, that it operated in one of the 13 sectors, and that it employed at least 50 persons. Smaller organizations were excluded because previous studies suggested that very few of them would use formal employment practices. We contacted selected organizations to ascertain whether they met these four criteria.

Response rate. - We contacted 620 organizations that met the inclusion criteria, and we received completed questionnaires from exactly 300 of them-a response rate of $48 \% .^{7}$ Despite the fact that we telephoned respondents, and other members of their organizations, in order to clarify responses and fill in blanks, we had to exclude 21 of the 300 questionnaires from the analysis due to the poor quality of the data. This brings the successful completion rate down to $45 \%$, which compares favorably with other organizational studies: Blau et al. (1976) report a rate of $36 \%$, Lincoln and Kalleberg (1985) a rate of 35\%, and Edelman (1992) a rate

\footnotetext{
${ }^{7}$ We were never able to contact 86 of the nonrespondents to determine whether they met the sampling criteria. To calculate the response rate we assume that this entire group would have met the criteria.
} 
of $54 \%$ for a telephone interview. We believe that our sample exaggerates the use of ILM practices because having a personnel office may increase the likelihood of adopting ILM practices and of participating in our survey. This points to a possible problem with sample selection bias; however, the event-history framework we use minimizes this problem. That is, the data set includes many cases (annual organizational spells) without personnel departments, particularly in the early years. Bias may also result from the fact that our retrospective data collection effort necessarily excludes failed organizations. The only realistic remedy would be longitudinal data collection which, if begun in 1985 , would have prevented us from examining the historical processes of interest.

\section{Measurement and Model Specification}

Dependent variables. - We examine the rate of adoption of six personnel practices: job descriptions, performance evaluations, salary classification systems, job ladders, employment testing, and promotion testing. Formal job descriptions outline the work to be performed in each job and the prerequisites for job applicants; they thereby enable the organization to identify a pool of internal candidates for each vacant position. Periodic, written performance evaluations are conducted by supervisors and results are kept on record for use in promotion decisions. Salary classification systems arrange jobs in a series of hierarchical wage categories based on requisite duties and skills; the creation of categories that are consistent across departments enables managers to determine which job shifts constitute lateral moves and which constitute vertical moves. Each formal job ladder specifies a succession of jobs in a sequence that constitute an expected promotion pattern. Written employment tests are designed to evaluate applicants' intelligence, experience, and personal character in order to match them with jobs, and promotion tests are used to judge current employees for promotion. It is important to note that formal ILM procedures may be poor indicators of whether organizations practice internal promotion, because organizations that lack these procedures may nonetheless routinely promote from within and organizations with these procedures may routinely hire from the external labor market.

To code each practice in event-history format, we asked respondents whether their organization had ever used the practice. For each affirmative response, we coded the year in which the practice was first used; if the practice had been abandoned we coded the year in which that occurred.

Independent variables. - Table 1 lists the independent variables. All vary over time, and all but the time periods, time trend, and density are measured at the organizational level. Our predictions about the effects 
TABLE 1

VARIABLE LIST

\begin{tabular}{|c|c|}
\hline Variable & Description \\
\hline Log employment & $\begin{array}{l}\text { Natural logarithm of the number of employees } \\
\text { reported in the current year }\end{array}$ \\
\hline Personnel office .......... & $\begin{array}{l}\text { Binary variable for presence of a personnel of- } \\
\text { fice in the current year }\end{array}$ \\
\hline Member of personnel association & $\begin{array}{l}\text { Binary variable for membership in a personnel } \\
\text { association in current year }\end{array}$ \\
\hline Period 2 & $\begin{array}{l}\text { Binary variable for spells occurring between } \\
1964 \text { and } 1973 \text {, inclusive }\end{array}$ \\
\hline Period 3 & $\begin{array}{l}\text { Binary variable for spells occurring between } \\
1974 \text { and } 1985, \text { inclusive }\end{array}$ \\
\hline Time trend & $\begin{array}{l}\text { Linear variable representing years since } 1954 \\
(1-30)\end{array}$ \\
\hline 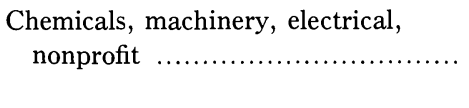 & $\begin{array}{l}\text { Binary variable for organization operating in } \\
\text { the sector }\end{array}$ \\
\hline City, county, federal government ..... & Binary variable for government agency \\
\hline Density (for each ILM practice)* ..... & $\begin{array}{l}\text { Percentage of firms in the sample reporting the } \\
\text { use of the practice in current year }\end{array}$ \\
\hline Federal contractor* & $\begin{array}{l}\text { Binary variable for federal contracts in current } \\
\text { year (limited to private organizations) }\end{array}$ \\
\hline EEO reporting status* & $\begin{array}{l}\text { Binary variable for organizations that filed an } \\
\text { EEO report with the EEOC or the OFCCP } \\
\text { in current year (limited to private organiza- } \\
\text { tions) }\end{array}$ \\
\hline AA office/officer* & $\begin{array}{l}\text { Binary variable for presence of affirmative ac- } \\
\text { tion office, or designated officer, in current } \\
\text { year }\end{array}$ \\
\hline Union contract* & $\begin{array}{l}\text { Binary variable for presence of union contract } \\
\text { in current year }\end{array}$ \\
\hline
\end{tabular}

* These variables are excluded from the results reported in tables 3-7 as they showed no effects in multivariate analyses.

of policy shifts vary. The omitted period is $1955-63\left(c_{1}\right)$, the first phase of EEO law is 1964-73 $\left(c_{2}\right)$, and the second phase is 1974-85 $\left(c_{3}\right)$. For job descriptions, performance evaluations, and salary classification we predict that $c_{1}<c_{2}<c_{3}$. For employment and promotion tests we predict that $c_{1}\left\langle c_{2}\right\rangle c_{3}$. We predict that the rate of adoption of job ladders will rise only in the third period, and principally for public organizations. The sectoral variables represent neoclassical arguments about firmspecific skills (i.e., chemical, machinery, electrical equipment industries) and institutional arguments about what types of employers are susceptible to new procedural norms (nonprofit and government organizations). 


\section{Estimation}

Before turning to methods and modeling, we show changes in the prevalence of the six personnel practices. Figure 1 reports the proportion of existing organizations that used each of the practices in each year. Changes are dramatic over time. While a small proportion of organizations used performance evaluations, job descriptions, and salary classification systems in 1955, a majority of sampled firms used these three practices by 1985 . It is evident that these first three practices grew more quickly between 1964 and 1973 than they did before 1964; they grew even more quickly between 1974 and 1985. By contrast, employment tests, which were at first more prevalent than any other practice, diverge notably from the first three practices after the early 1960s. Promotion tests and job ladders rise very slowly in absolute terms. Table 2 reports the average annual hazard rate for each of the six outcomes, in each of the three policy periods. These figures tell a similar story about the positive effects of legal changes on the first three variables in both periods 2 and 3. They also support our hypothesis that job ladders should increase in period 3, and that employment testing should increase between periods 1 and 2 but not between periods 2 and 3 .

Tables 3-7 present loglinear event-history models, estimated with Tuma's RATE program, for five of the six ILM practices. Over the 30-year time frame we cover, the 279 organizations sampled yield 6,701 annual

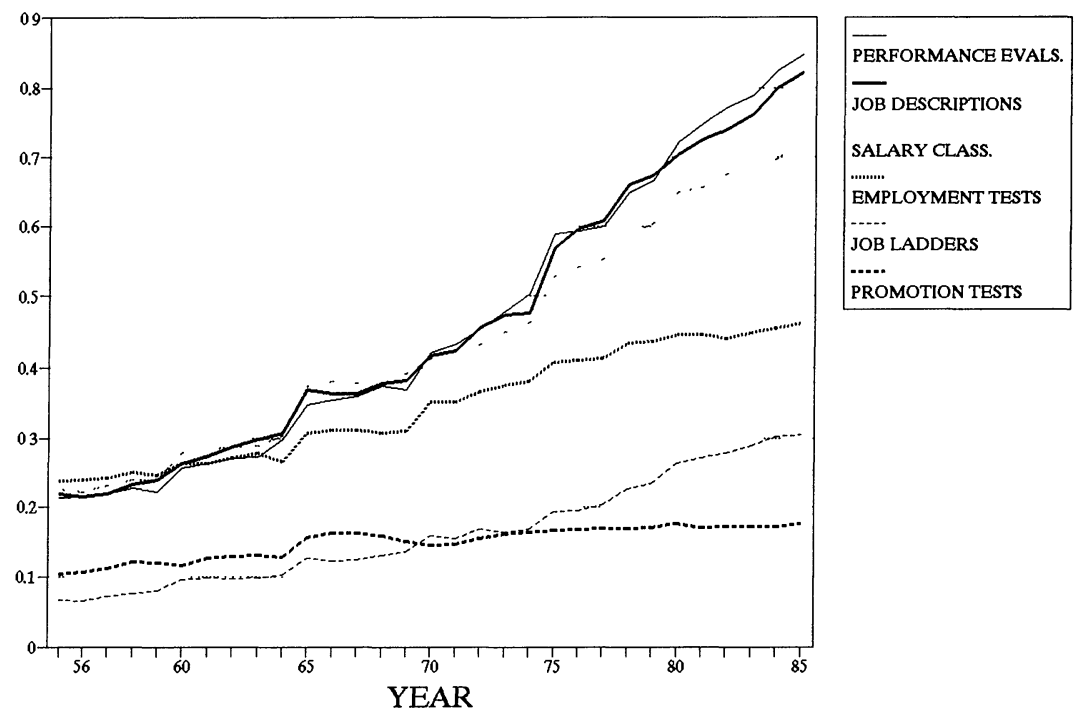

FIG. 1.-Proportion of sample with ILM practices 
TABLE 2

Average Annual Hazard Rate for Each Internal Labor Market Practice

\begin{tabular}{cccc}
\hline \multicolumn{1}{c}{ ILM Practice } & $\begin{array}{c}\text { Period 1 } \\
(1955-63)\end{array}$ & $\begin{array}{c}\text { Period 2 } \\
(1964-73)\end{array}$ & $\begin{array}{c}\text { Period } 3 \\
(1974-85)\end{array}$ \\
\hline Job descriptions $\ldots \ldots \ldots \ldots \ldots \ldots \ldots \ldots \ldots$ & .015 & .036 & .095 \\
Performance evaluations $\ldots \ldots \ldots \ldots \ldots \ldots$ & .011 & .039 & .099 \\
Salary classification $\ldots \ldots \ldots \ldots \ldots \ldots \ldots \ldots$ & .013 & .031 & .061 \\
Job ladders $\ldots \ldots \ldots \ldots \ldots \ldots \ldots \ldots \ldots \ldots$ & .005 & .009 & .017 \\
Employment testing $\ldots \ldots \ldots \ldots \ldots \ldots \ldots$ & .009 & .024 & .023 \\
Promotion testing $\ldots \ldots \ldots \ldots \ldots \ldots \ldots \ldots$ & .006 & .007 & .004 \\
\hline
\end{tabular}

spells of observation. In the models, organizations are excluded from the at-risk pool before their birth, and after they have adopted a practice. The number of at-risk spells ranges from 3,400 to 5,396 for the five modeled outcomes. The number of transitions modeled ranges from 61 to 164 . We treat as left censored organizations that adopted the modeled practice before 1955 as well as those founded after 1955 that started out with the modeled practice. For each outcome we present equations that include, in addition to other variables, (1) the two binary time-period variables representing changes in EEO law, (2) a time-trend variable, and (3) the time-period variables as well as the time trend. Our aim here is to discern either a linear increase in the likelihood of adopting ILM practices, which might be caused by any number of factors, or stepwise increases that correspond to legal changes. We also report the effects of the two time-period variables and the time-trend variable separately because they are multicollinear.

\section{FINDINGS}

Rationalist arguments are weakly supported by our analyses. Contrary to rationalist arguments that size is the most important cause of the formalization of organizational personnel practices, employment size shows significant effects for only two of the outcome variables. Neoclassical economic arguments that organizations employ ILMs to guard firmspecific skills in capital-intensive, modern sectors receive some support. In accord with those predictions, electrical equipment industries showed positive effects on two outcomes and chemical industries showed an effect on one. Machinery produced no significant effects. Parenthetically, we tested all other sectors for significant positive effects and found none. On the whole, public and nonprofit organizations were most likely to adopt these practices, as institutional theory predicts. The density measures representing the proportion of the sample with the specified practice in 
TABLE 3

Estimates of Factors Affecting the Adoption of Job Descriptions, 1956-85

\begin{tabular}{|c|c|c|c|c|c|c|c|c|c|c|c|c|c|c|c|}
\hline \multirow[b]{2}{*}{ EQUATION } & \multirow[b]{2}{*}{ INTERCEPT } & \multirow[b]{2}{*}{$\begin{array}{c}\text { LOG } \\
\text { EMPLOY- } \\
\text { MENT }\end{array}$} & \multirow[b]{2}{*}{$\begin{array}{c}\text { Presence } \\
\text { of a } \\
\text { Personnel } \\
\text { OfFice }\end{array}$} & \multirow{2}{*}{$\begin{array}{c}\text { Member } \\
\text { OF A } \\
\text { PERSONNEL } \\
\text { Asso- } \\
\text { CIATION }\end{array}$} & \multirow[b]{2}{*}{$\begin{array}{l}\text { PERIOD 2 } \\
(1964-73)\end{array}$} & \multirow[b]{2}{*}{$\begin{array}{l}\text { PERIOD } 3 \\
(1974-85)\end{array}$} & \multirow[b]{2}{*}{$\begin{array}{c}\text { Time } \\
\text { Trend }\end{array}$} & \multicolumn{7}{|c|}{ SECTOR $^{a}$} & \multirow[b]{2}{*}{$x^{2}$} \\
\hline & & & & & & & & $\begin{array}{l}\text { Chem- } \\
\text { 1cals }\end{array}$ & $\begin{array}{c}\text { Machın- } \\
\text { ery }\end{array}$ & $\begin{array}{l}\text { Elec- } \\
\text { trical }\end{array}$ & Nonprofit & $\begin{array}{c}\text { City } \\
\text { Govern- } \\
\text { ment }\end{array}$ & $\begin{array}{c}\text { County } \\
\text { Govern- } \\
\text { ment }\end{array}$ & $\begin{array}{c}\text { Federal } \\
\text { Govern- } \\
\text { ment }\end{array}$ & \\
\hline (1) $\ldots \ldots \ldots \ldots$ & $\begin{array}{c}-5.704^{* *} \\
(.439)\end{array}$ & $\begin{array}{l}.165^{*} \\
(.068)\end{array}$ & $\begin{array}{l}.460 * \\
(.186)\end{array}$ & $\begin{array}{l}.303 \\
(.240)\end{array}$ & $\begin{array}{l}1.059^{* *} \\
(.301)\end{array}$ & $\begin{array}{l}2.164^{* *} \\
(.291)\end{array}$ & & $\begin{array}{l}.285 \\
(.326)\end{array}$ & $\begin{array}{l}.129 \\
(277)\end{array}$ & $\begin{array}{l}.079 \\
(.306)\end{array}$ & $\begin{array}{l}1.171^{* *} \\
(.271)\end{array}$ & $\begin{array}{l}.899 * * \\
(.319)\end{array}$ & $\begin{array}{l}1.540^{* *} \\
(.274)\end{array}$ & $\begin{array}{l}.252 \\
(.719)\end{array}$ & 13692 \\
\hline (2) $\ldots \ldots \ldots \ldots$ & $\begin{array}{c}-5.962^{* *} \\
(.423)\end{array}$ & $\begin{array}{l}.160^{*} \\
(.068)\end{array}$ & $\begin{array}{l}.457^{*} \\
(.187)\end{array}$ & $\begin{array}{l}.216 \\
(.244)\end{array}$ & & & $\begin{array}{l}.099^{* *} \\
(.011)\end{array}$ & $\begin{array}{l}.291 \\
(.325)\end{array}$ & $\begin{array}{l}.093 \\
(.277)\end{array}$ & $\begin{array}{l}.106 \\
(.307)\end{array}$ & $\begin{array}{l}1.242 * * \\
(.274)\end{array}$ & $\begin{array}{l}.974^{* *} \\
(.322)\end{array}$ & $\begin{array}{l}1.599^{* *} \\
(.277)\end{array}$ & $\begin{array}{l}.198 \\
(.719)\end{array}$ & 13405 \\
\hline (3) $\ldots \ldots \ldots \ldots$ & $\begin{array}{c}-5.958^{* *} \\
(.465)\end{array}$ & $\begin{array}{l}.168^{*} \\
(.068)\end{array}$ & $\begin{array}{l}.449 * \\
(.187)\end{array}$ & $\begin{array}{l}.248 \\
(.243)\end{array}$ & $\begin{array}{l}.653 \\
(.373)\end{array}$ & $\begin{array}{l}1.288^{*} \\
(.549)\end{array}$ & $\begin{array}{l}.046 \\
(.025)\end{array}$ & $\begin{array}{l}.294 \\
(.326)\end{array}$ & $\begin{array}{l}.112 \\
(.277)\end{array}$ & $\begin{array}{l}.091 \\
(307)\end{array}$ & $\begin{array}{l}1.236^{* *} \\
(.274)\end{array}$ & $\begin{array}{l}.949 * * \\
(.321)\end{array}$ & $\begin{array}{l}1.603^{* * *} \\
(.277)\end{array}$ & $\begin{array}{l}.219 \\
(720)\end{array}$ & 149.69 \\
\hline
\end{tabular}

Note. - No. of cases at risk $=223$; left-censored cases $=56$; no. of transitions $=164$. SEs are shown in parentheses. $N=3,436$ spells

a Omitted sectors are publishing, banking, retail trade, transportation, hospitals, and state government.

$* P \leq .05$.

$* * P \leq .01$. 
TABLE 4

Estimates of Factors Affecting the Adoption of Performance Evaluations, 1956-85

\begin{tabular}{|c|c|c|c|c|c|c|c|c|c|c|c|c|c|c|c|}
\hline \multirow[b]{2}{*}{ EQUATION } & \multirow[b]{2}{*}{ INTERCEPT } & \multirow[b]{2}{*}{$\begin{array}{c}\text { LOG } \\
\text { EMPLOY- } \\
\text { MENT }\end{array}$} & \multirow{2}{*}{$\begin{array}{c}\text { Presence } \\
\text { OF A } \\
\text { PeRsonNel } \\
\text { OfFICE }\end{array}$} & \multirow{2}{*}{$\begin{array}{c}\text { Member } \\
\text { OF A } \\
\text { PERSONNEL } \\
\text { Asso- } \\
\text { CIATION }\end{array}$} & \multirow[b]{2}{*}{$\begin{array}{l}\text { PERIOD 2 } \\
\text { (1964-73) }\end{array}$} & \multirow[b]{2}{*}{$\begin{array}{l}\text { PERIOD } 3 \\
(1974-85)\end{array}$} & \multirow[b]{2}{*}{$\begin{array}{c}\text { Time } \\
\text { TREND }\end{array}$} & \multicolumn{7}{|c|}{ SECTOR $^{a}$} & \multirow[b]{2}{*}{$x^{2}$} \\
\hline & & & & & & & & $\begin{array}{l}\text { Chem- } \\
\text { icals }\end{array}$ & $\begin{array}{l}\text { Machin- } \\
\text { ery }\end{array}$ & $\begin{array}{l}\text { Elec- } \\
\text { trical }\end{array}$ & Nonprofit & $\begin{array}{c}\text { City } \\
\text { Govern- } \\
\text { ment }\end{array}$ & $\begin{array}{c}\text { County } \\
\text { Govern- } \\
\text { ment }\end{array}$ & $\begin{array}{c}\text { Federal } \\
\text { Govern- } \\
\text { ment }\end{array}$ & \\
\hline (1) $\ldots \ldots \ldots$ & $\begin{array}{c}-5.906^{* *} \\
(457)\end{array}$ & $\begin{array}{l}.150 * \\
(.065)\end{array}$ & $\begin{array}{c}.467 * \\
(.188)\end{array}$ & $\begin{array}{c}.091 \\
(.234)\end{array}$ & $\begin{array}{l}1.382^{* *} \\
(.334)\end{array}$ & $\begin{array}{l}2.326^{* *} \\
(.327)\end{array}$ & & $\begin{array}{l}.753^{*} \\
(.299)\end{array}$ & $\begin{array}{c}.179 \\
(.268)\end{array}$ & $\begin{array}{c}.938^{*} \\
(.299)\end{array}$ & $\begin{array}{l}1.047^{* *} \\
(.269)\end{array}$ & $\begin{array}{l}.483 \\
(.330)\end{array}$ & $\begin{array}{l}1.214^{* *} \\
(.285)\end{array}$ & $\begin{array}{c}.398 \\
(517)\end{array}$ & 136.78 \\
\hline (2) $\ldots \ldots \ldots$ & $\begin{array}{c}-5.950^{* *} \\
(.420)\end{array}$ & $\begin{array}{c}.152^{*} \\
(.066)\end{array}$ & $\begin{array}{c}.452^{*} \\
(.188)\end{array}$ & $\begin{array}{c}.013 \\
(.237)\end{array}$ & & & $\begin{array}{l}.097 * * \\
(.011)\end{array}$ & $\begin{array}{l}.789 * * \\
(.299)\end{array}$ & $\begin{array}{l}.166 \\
(.268)\end{array}$ & $\begin{array}{l}.959^{* *} \\
(.300)\end{array}$ & $\begin{array}{l}1.128^{* *} \\
(.271)\end{array}$ & $\begin{array}{l}.560 \\
(.330)\end{array}$ & $\begin{array}{l}1.262^{* *} \\
(.288)\end{array}$ & $\begin{array}{l}.413 \\
(.517)\end{array}$ & 131.09 \\
\hline (3) $\ldots \ldots \ldots \ldots$ & $\begin{array}{c}-6.134 * * \\
(.485)\end{array}$ & $\begin{array}{l}.155^{*} \\
(.066)\end{array}$ & $\begin{array}{l}.456^{*} \\
(.188)\end{array}$ & $\begin{array}{l}.041 \\
(.237)\end{array}$ & $\begin{array}{l}1.036^{*} \\
(.403)\end{array}$ & $\begin{array}{l}1.590^{* *} \\
(.578)\end{array}$ & $\begin{array}{l}.040 \\
(.026)\end{array}$ & $\begin{array}{l}.779^{*} \\
(.299)\end{array}$ & $\begin{array}{c}171 \\
(.268)\end{array}$ & $\begin{array}{l}.950^{* *} \\
(.299)\end{array}$ & $\begin{array}{l}1092 * * \\
(.271)\end{array}$ & $\begin{array}{l}.521 \\
(.331)\end{array}$ & $\begin{array}{l}1.265^{* *} \\
(.288)\end{array}$ & $\begin{array}{l}.405 \\
(.517)\end{array}$ & 139.19 \\
\hline
\end{tabular}

NotE. - No. of cases at risk $=215$; left-censored cases $=64$; no. of transitions $=162$, SEs are shown in parentheses. $N=3,400$ spells.

${ }^{a}$ Omitted sectors are publishing, banking, retail trade, transportation, hospitals, and state government.

$* P \leq .05$.

** $P \leq .01$. 
TABLE 5

Estimates of Factors Affecting the Adoption of Salary Classification, 1956-85

\begin{tabular}{|c|c|c|c|c|c|c|c|c|c|c|c|c|c|c|c|}
\hline \multirow[b]{2}{*}{ EQUATION } & \multirow[b]{2}{*}{ INTERCEPT } & \multirow[b]{2}{*}{$\begin{array}{c}\text { LOG } \\
\text { EMPLOY- } \\
\text { MENT }\end{array}$} & \multirow[b]{2}{*}{$\begin{array}{c}\text { Presence } \\
\text { of a } \\
\text { PersonNel } \\
\text { OfFICE }\end{array}$} & \multirow{2}{*}{$\begin{array}{c}\text { MEMbER } \\
\text { OF A } \\
\text { PERSONNEL } \\
\text { ASSO- } \\
\text { CIATION }\end{array}$} & \multirow[b]{2}{*}{$\begin{array}{l}\text { PERIOD 2 } \\
\text { (1964-73) }\end{array}$} & \multirow[b]{2}{*}{$\begin{array}{l}\text { PERIOD } 3 \\
(1974-85)\end{array}$} & \multirow[b]{2}{*}{$\begin{array}{c}\text { Time } \\
\text { TREND }\end{array}$} & \multicolumn{7}{|c|}{ SECTOR ${ }^{a}$} & \multirow[b]{2}{*}{$x^{2}$} \\
\hline & & & & & & & & $\begin{array}{l}\text { Chem- } \\
\text { icals }\end{array}$ & $\begin{array}{l}\text { Machin- } \\
\text { ery }\end{array}$ & $\begin{array}{l}\text { Elec- } \\
\text { trical }\end{array}$ & Nonprofit & $\begin{array}{l}\text { City } \\
\text { Govern- } \\
\text { ment }\end{array}$ & $\begin{array}{l}\text { County } \\
\text { Govern- } \\
\text { ment }\end{array}$ & $\begin{array}{c}\text { Federal } \\
\text { Govern- } \\
\text { ment }\end{array}$ & \\
\hline (1) $\ldots \ldots \ldots \ldots$ & $\begin{array}{c}-5.906^{* *} \\
(.471)\end{array}$ & $\begin{array}{c}.135 \\
(.072)\end{array}$ & $\begin{array}{l}.750 * * \\
(.207)\end{array}$ & $\begin{array}{c}.460 \\
(.240)\end{array}$ & $\begin{array}{l}.970 * * \\
(.323)\end{array}$ & $\begin{array}{l}1.680^{* *} \\
(.315)\end{array}$ & & $\begin{array}{l}.132 \\
(.382)\end{array}$ & $\begin{array}{l}.504 \\
(.315)\end{array}$ & $\begin{array}{l}1.078^{* *} \\
(.301)\end{array}$ & $\begin{array}{l}1.049 * * \\
(.282)\end{array}$ & $\begin{array}{l}.996^{* *} \\
(.366)\end{array}$ & $\begin{array}{l}1.768^{* *} \\
(.301)\end{array}$ & $\begin{array}{l}.870 \\
(.725)\end{array}$ & 118.58 \\
\hline (2) $\ldots \ldots \ldots$ & $\begin{array}{c}-5.667 * * \\
(.433)\end{array}$ & $\begin{array}{l}.121 \\
(.071)\end{array}$ & $\begin{array}{l}.763^{* *} \\
(.208)\end{array}$ & $\begin{array}{c}.465 \\
(.243)\end{array}$ & & & $\begin{array}{l}.058^{* *} \\
(.012)\end{array}$ & $\begin{array}{c}.118 \\
(.382)\end{array}$ & $\begin{array}{c}.509 \\
(.315)\end{array}$ & $\begin{array}{l}1.080^{* *} \\
(.301)\end{array}$ & $\begin{array}{l}1.047^{* *} \\
(.283)\end{array}$ & $\begin{array}{l}.987 * * \\
(.367)\end{array}$ & $\begin{array}{l}1.704^{* *} \\
(.303)\end{array}$ & $\begin{array}{c}.844 \\
(.725)\end{array}$ & 104.40 \\
\hline (3) $\ldots \ldots \ldots \ldots$ & $\begin{array}{c}-5.710^{* *} \\
(.487)\end{array}$ & $\begin{array}{l}.133 \\
(.071)\end{array}$ & $\begin{array}{l}.763^{* *} \\
(.206)\end{array}$ & $\begin{array}{l}.506^{*} \\
(.241)\end{array}$ & $\begin{array}{l}1.324^{* *} \\
(.404)\end{array}$ & $\begin{array}{l}2.436 * * \\
(.609)\end{array}$ & $\begin{array}{r}-.040 \\
(.028)\end{array}$ & $\begin{array}{l}.132 \\
(.382)\end{array}$ & $\begin{array}{c}.507 \\
(.315)\end{array}$ & $\begin{array}{l}1.083^{* *} \\
(.301)\end{array}$ & $\begin{array}{l}1.017^{* *} \\
(.283)\end{array}$ & $\begin{array}{l}.980 * * \\
(.367)\end{array}$ & $\begin{array}{l}1.715^{* *} \\
(.302)\end{array}$ & $\begin{array}{c}.894 \\
(.725)\end{array}$ & 120.67 \\
\hline
\end{tabular}

Note. - No. of cases at risk $=220$; left-censored cases $=59$; no. of transitions $=132$; SEs are shown in parentheses. $N=3,600$ spells.

${ }^{a}$ Omitted sectors are publishing, banking, retail trade, transportation, hospitals, and state government.

$* P \leq .05$.

$* * P \leq .01$. 
TABLE 6

Estimates of Factors Affecting the Adoption of Job Ladders, 1956-85

\begin{tabular}{|c|c|c|c|c|c|c|c|c|c|c|c|c|c|c|c|}
\hline \multirow[b]{2}{*}{ EQUATION } & \multirow[b]{2}{*}{ INTERCEPT } & \multirow[b]{2}{*}{$\begin{array}{c}\text { LOG } \\
\text { EMPLOY- } \\
\text { MENT }\end{array}$} & \multirow[b]{2}{*}{$\begin{array}{c}\text { Presence } \\
\text { of a } \\
\text { Personnel } \\
\text { Office }\end{array}$} & \multirow{2}{*}{$\begin{array}{c}\text { MEMber } \\
\text { OF A } \\
\text { PERSONNEL } \\
\text { Asso- } \\
\text { CIATION }\end{array}$} & \multirow[b]{2}{*}{$\begin{array}{l}\text { PERIOD 2 } \\
\text { (1964-73) }\end{array}$} & \multirow[b]{2}{*}{$\begin{array}{l}\text { PERIOD 3 } \\
\text { (1974-85) }\end{array}$} & \multirow[b]{2}{*}{$\begin{array}{c}\text { TIME } \\
\text { TREND }\end{array}$} & \multicolumn{7}{|c|}{ SECTOR $^{\mathrm{a}}$} & \multirow[b]{2}{*}{$x^{2}$} \\
\hline & & & & & & & & $\begin{array}{l}\text { Chem- } \\
\text { icals }\end{array}$ & $\begin{array}{l}\text { Machin- } \\
\text { ery }\end{array}$ & $\begin{array}{l}\text { Elec- } \\
\text { trical }\end{array}$ & Nonprofit & $\begin{array}{l}\text { City } \\
\text { Govern- } \\
\text { ment }\end{array}$ & $\begin{array}{c}\text { County } \\
\text { Govern- } \\
\text { ment }\end{array}$ & $\begin{array}{c}\text { Federal } \\
\text { Govern- } \\
\text { ment }\end{array}$ & \\
\hline (1) .......... & $\begin{array}{c}-6.778^{* *} \\
(.650)\end{array}$ & $\begin{array}{l}.151 \\
(.096)\end{array}$ & $\begin{array}{l}.404 \\
(.323)\end{array}$ & $\begin{array}{l}.164 \\
(.328)\end{array}$ & $\begin{array}{l}.589 \\
(.481)\end{array}$ & $\begin{array}{l}.114^{*} \\
(.455)\end{array}$ & & $\begin{array}{l}.601 \\
(.553)\end{array}$ & $\begin{array}{l}.571 \\
(.508)\end{array}$ & $\begin{array}{l}.781 \\
(.509)\end{array}$ & $\begin{array}{c}.672 \\
(.399)\end{array}$ & $\begin{array}{c}.646 \\
(.551)\end{array}$ & $\begin{array}{l}1.508^{* *} \\
(.388)\end{array}$ & $\begin{array}{l}1.434^{*} \\
(.628)\end{array}$ & 36.97 \\
\hline (2) $\ldots \ldots \ldots \ldots$ & $\begin{array}{c}-6.628^{* *} \\
(.608)\end{array}$ & $\begin{array}{l}.146 \\
(.095)\end{array}$ & $\begin{array}{l}.422 \\
(.323)\end{array}$ & $\begin{array}{l}.194 \\
(.334)\end{array}$ & & & $\begin{array}{l}.366^{*} \\
(.173)\end{array}$ & $\begin{array}{l}.591 \\
(.553)\end{array}$ & $\begin{array}{l}.578 \\
(.508)\end{array}$ & $\begin{array}{l}.787 \\
(.509)\end{array}$ & $\begin{array}{l}.673 \\
(.399)\end{array}$ & $\begin{array}{l}.658 \\
(.551)\end{array}$ & $\begin{array}{l}1.481^{* *} \\
(.388)\end{array}$ & $\begin{array}{l}1.420 * \\
(.629)\end{array}$ & 32.98 \\
\hline (3) $\ldots \ldots \ldots \ldots$ & $\begin{array}{c}-6.549 * * \\
(.671)\end{array}$ & $\begin{array}{l}.147 \\
(.095)\end{array}$ & $\begin{array}{l}.419 \\
(.322)\end{array}$ & $\begin{array}{l}.229 \\
(.322)\end{array}$ & $\begin{array}{l}1.025 \\
(.600)\end{array}$ & $\begin{array}{l}2.090 * \\
(.901)\end{array}$ & $\begin{array}{r}-.049 \\
(.041)\end{array}$ & $\begin{array}{l}.595 \\
(.553)\end{array}$ & $\begin{array}{l}.579 \\
(.509)\end{array}$ & $\begin{array}{l}.794 \\
(.509)\end{array}$ & $\begin{array}{l}.657 \\
(.399)\end{array}$ & $\begin{array}{l}.635 \\
(.551)\end{array}$ & $\begin{array}{l}1.480 * * \\
(.388)\end{array}$ & $\begin{array}{l}1.417^{*} \\
(.629)\end{array}$ & 38.42 \\
\hline
\end{tabular}

Note. - No. of cases at risk $=257$; left-censored cases $=22$; no. of transitions $=61$; SEs are shown in parentheses. $N=5,396$ spells.

${ }^{a}$ Omitted sectors are publishing, banking, retail trade, transportation, hospitals, and state government.

$* P \leq .05$.

$* * P \leq .01$. 
TABLE 7

Estimates of Factors Affecting the Adoption of Employment Tests, 1956-85

\begin{tabular}{|c|c|c|c|c|c|c|c|c|c|c|c|c|c|c|c|}
\hline \multirow[b]{2}{*}{ EQUATION } & \multirow[b]{2}{*}{ INTERCEPT } & \multirow[b]{2}{*}{$\begin{array}{l}\text { LOG } \\
\text { EMPLOY- } \\
\text { MENT }\end{array}$} & \multirow{2}{*}{$\begin{array}{c}\text { PRESENCE } \\
\text { OF A } \\
\text { PERSONNEL } \\
\text { OfFICE }\end{array}$} & \multirow{2}{*}{$\begin{array}{c}\text { MEMBER } \\
\text { OF A } \\
\text { PERSONNEL } \\
\text { AsSO- } \\
\text { CIATION }\end{array}$} & \multirow[b]{2}{*}{$\begin{array}{l}\text { PERIOD } 2 \\
\text { (1964-73) }\end{array}$} & \multirow[b]{2}{*}{$\begin{array}{l}\text { PERIOD } 3 \\
\text { (1974-85) }\end{array}$} & \multirow[b]{2}{*}{$\begin{array}{c}\text { TIME } \\
\text { TREND }\end{array}$} & \multicolumn{7}{|c|}{ SECTOR $^{a}$} & \multirow[b]{2}{*}{$x^{2}$} \\
\hline & & & & & & & & $\begin{array}{l}\text { Chem- } \\
\text { icals }\end{array}$ & $\begin{array}{c}\text { Machın- } \\
\text { ery }\end{array}$ & $\begin{array}{l}\text { Elec- } \\
\text { trical }\end{array}$ & Nonprofit & $\begin{array}{c}\text { City } \\
\text { Govern- } \\
\text { ment }\end{array}$ & $\begin{array}{c}\text { County } \\
\text { Govern- } \\
\text { ment }\end{array}$ & $\begin{array}{c}\text { Federal } \\
\text { Govern- } \\
\text { ment }\end{array}$ & \\
\hline (1) $\ldots \ldots . .$. & $\begin{array}{c}-5.596^{* *} \\
(.524)\end{array}$ & $\begin{array}{l}.097 \\
(.083)\end{array}$ & $\begin{array}{l}.080 \\
(.285)\end{array}$ & $\begin{array}{r}-.073 \\
(.347)\end{array}$ & $\begin{array}{l}1.113^{* *} \\
(.395)\end{array}$ & $\begin{array}{l}1.112^{* *} \\
(.249)\end{array}$ & & $\begin{array}{l}.196 \\
(.488)\end{array}$ & $\begin{array}{l}.384 \\
(.365)\end{array}$ & $\begin{array}{l}.403 \\
(.454)\end{array}$ & $\begin{array}{r}-.165 \\
(.434)\end{array}$ & $\begin{array}{l}1.353^{* *} \\
(.402)\end{array}$ & $\begin{array}{l}1.045^{* *} \\
(.357)\end{array}$ & $\begin{array}{l}.212 \\
(.610)\end{array}$ & 26.49 \\
\hline (2) $\quad \ldots \ldots \ldots$ & $\begin{array}{c}-5.195^{* *} \\
(.474)\end{array}$ & $\begin{array}{l}.102 \\
(.082)\end{array}$ & $\begin{array}{l}.061 \\
(.284)\end{array}$ & $\begin{array}{c}-.121 \\
(.347)\end{array}$ & & & $\begin{array}{l}.029^{*} \\
(015)\end{array}$ & $\begin{array}{c}.211 \\
(.488)\end{array}$ & $\begin{array}{c}.395 \\
(.365)\end{array}$ & $\begin{array}{c}.437 \\
(.453)\end{array}$ & $\begin{array}{r}-.160 \\
(.434)\end{array}$ & $\begin{array}{l}1.369^{* *} \\
(.402)\end{array}$ & $\begin{array}{l}1.022 * * \\
(.358)\end{array}$ & $\begin{array}{c}.202 \\
(.700)\end{array}$ & 19.03 \\
\hline (3) $\ldots \ldots \ldots$ & $\begin{array}{c}-5.460 * * \\
(.549)\end{array}$ & $\begin{array}{l}.095 \\
(.082)\end{array}$ & $\begin{array}{c}.096 \\
(.285)\end{array}$ & $\begin{array}{c}-.036 \\
(.349)\end{array}$ & $\begin{array}{l}1.366^{* *} \\
(.509)\end{array}$ & $\begin{array}{l}1.661 * \\
(.803)\end{array}$ & $\begin{array}{r}-.028 \\
(.036)\end{array}$ & $\begin{array}{c}190 \\
(.488)\end{array}$ & $\begin{array}{c}.381 \\
(.365)\end{array}$ & $\begin{array}{c}.397 \\
(.454)\end{array}$ & $\begin{array}{c}-.172 \\
(.434)\end{array}$ & $\begin{array}{l}1.336^{* *} \\
(.402)\end{array}$ & $\begin{array}{l}1.029 * * \\
(.357)\end{array}$ & $\begin{array}{c}.214 \\
(.610)\end{array}$ & 27.10 \\
\hline
\end{tabular}

Note. - No. of cases at risk $=233$; left-censored cases $=46 ;$ no. of transitions $=81$; SEs are shown in parentheses. $N=4,104$ spells.

a Omitted sectors are publishing, banking, retail trade, transportation, hospitals, and state government.

$* P \leq .05$.

** $P \leq .01$. 
the current year, which operationalize the argument that organizations install ILM mechanisms to compete for labor, performed well in bivariate analyses, but their effects disappeared in multivariate models. For parsimony we omit the density measures from the reported results, as well as several other variables that showed no significant effects in multivariate models.

Conflict arguments do not receive support here. Pfeffer and Cohen (1984) suggest that personnel departments have positive effects and unions have negative effects. Their argument hinges on the struggle between these two interests; the theory depends on our finding both effects. We found strong positive effects of personnel departments, but no effects of union contracts in either bivariate or multivariate models.

Legal changes show strong effects. The time periods, which represent changes in the legal environment, were important in all of our models. In accord with our predictions, the period effects are consistently positive, and the period 3 coefficients exceed the period 2 coefficients for job descriptions, performance evaluations, and salary classification systems. In equation (1) of table 3 , for instance, the constant, which represents the baseline rate for the period $1955-63$, is -5.704 . To calculate the change in the rate of adoption between periods we add the parameter for period $2(1.059)$ to the constant, and the sum $(-4.645)$ shows that, between $c_{1}$ and $c_{2}$, the rate increases by about $19 \%$. Similarly, when we add the parameter for period 3 to the constant, the sum $(-3.540)$ shows that the rate increases by approximately $38 \%$ between $c_{1}$ and $c_{3}$. Very similar findings are presented for performance evaluations and salary classification. For job ladders, only period 3 shows a significant effect; this supports DiPrete's (1989) argument that civil service systems bridged job ladders to conform to EEO guidelines after the early 1970s. For employment tests, the parameters for the two later periods are roughly equal, which supports our argument that personnel professionals responded to the Civil Rights Act by encouraging adoption of such tests but that the legal precedents of the early 1970s made testing difficult to support in court. Some organizations undertook studies to demonstrate that tests predicted job performance, but many avoided testing altogether.

We introduce a time-trend variable to evaluate whether the period variables actually tap a steady secular increase in adoption rather than the discontinuous effects of policy shifts. If the former is the case, the time-trend variable, coded from 1-30, should wash out the effects of the binary time-period variables. This is not what happens. In constrained models the period variables produce better results than the time trend variable for all five outcomes. In unconstrained models that include all three variables, the time trend uniformly fails to achieve significance. 
For four of the outcomes, the time-period variables that show significant effects in equation (1) remain significant. For job descriptions, only period 2 shows significant effects. These results suggest that increases in the likelihood of adoption were stepwise and dramatic rather than incremental. While these general measures of legal change show robust effects, the direct measures of whether organizations come under federal EEO scrutiny-federal contractor status and EEO report filing statusshowed weak effects that did not hold up in multivariate models, hence we omit them from the tables.

The presence of a personnel office shows a positive effect on the adoption of job descriptions, performance evaluations, and salary classification, which were ultimately approved by the personnel profession and the courts as EEO compliance strategies, but not on job ladders or employment tests, which were generally discouraged by the profession and the courts. For one outcome, salary classification, membership in a personnel association also shows a weak net effect. In bivariate analyses the presence of an affirmative action office or officer showed a significant positive effect for four of the outcomes, but the fact that this measure washed out in multivariate analyses suggests that personnel networks, not affirmative action networks, were the most important interorganizational conduits of these practices.

Location in the "institutional" (nonprofit and government) sector showed an effect for every outcome despite the fact that many state and federal agencies used civil service systems, which incorporate our outcome variables, before 1955; the at-risk group includes relatively few state or federal agencies. By examining the constant $(-5.704)$ and parameters in equation (1) of table 3 we find that nonprofits (1.171) were $21 \%$ more likely to adopt job descriptions than organizations in the reference group, city agencies (.899) were $16 \%$ more likely, and county agencies (1.540) were $27 \%$ more likely. The nonprofit sector shows significant, positive effects in three of the equations; county governments show up in five; city governments show up in three; and the federal government shows up in one. In accord with DiPrete's argument that government agencies used bridged job ladders to achieve EEO compliance from the mid-1970s, we find that only county and federal governments show positive effects on job ladders, and only the 1974-85 time period shows an effect.

We do not present a table for promotion testing because only one factor had a significant bivariate effect. Personnel association membership produced a log-likelihood chi-square statistic of 4.71, with a coefficient of .894 and a standard error of .387 . The practice of promotion testing showed the slowest growth over the period and was the least prevalent 
of all of these practices by 1985; this supports our hypothesis that EEO case law discouraged employers from using tests to evaluate employees.

We believe that, taken together, these results demonstrate that since 1955 particular ILM practices diffused largely in response to shifts in the legal environment. They diffused through networks of personnel professionals who collectively devised organizational formulas for inoculation against EEO litigation. Organizations subject to public scrutiny were more likely to adopt these practices. Organizations subject to direct federal oversight in view of their contractor status were no more likely to adopt these practices than were other organizations because the process by which the practices spread is diffuse and normative rather than specific and coercive.

\section{CONCLUSION}

Organizational analysts have traditionally explained management practices by tracing their origins. This has been our strategy as well, and the process has led us to be skeptical about the very terms internal, labor, and market. Between the 1960s and 1980s, as in the 1930s and 1940s, organizations adopted formal promotion mechanisms in response to external changes as much as, or more than, in response to internal imperatives. They installed these mechanisms in reaction to the elaboration of employee rights, as well as to deal with problems associated with the management of labor (i.e., human capital). And they adopted these practices to conform to legal requirements, as well as to effect interior market mechanisms. We found that organizations adopt ILM practices less in response to internal imperatives than in response to changes in the general model of organizing offered by the environment.

Our findings concern the relationship between the state and organizations. In the United States, public policy governing organizational practices seldom takes the form of direct mandates; policies create broad rules about outcomes rather than specific rules about means to those outcomes. As a result, specific organizational means are worked out in the nexus between organizations and the state. Ambiguous public policies invite organizations to experiment with solutions that will withstand legal tests, and in turn the courts and Congress affirm certain strategies and veto others (Edelman 1992). This process contributed to the evolving understanding of what constitutes discrimination and how to guard against it (see Burstein 1990). In the case of EEO law, the courts discouraged the use of formal testing and made it clear that organizations that used voluntary quotas would open themselves up to reverse-discrimination litigation. But they approved the formalization of hiring and promotion 
through the use of traditional ILM practices. This procedural strategy became the favored approach to pursuing nondiscrimination. The process was diffuse and normative, rather than targeted and coercive, and this showed up in our finding that being a federal contractor, or coming under EEOC or OFCCP scrutiny, had no net effect. In short, public policy helped to create broad models of organizing that were embraced as just and rational by all sorts of organizations; it did not force a narrow range of targeted organizations to adopt specified practices in order to avoid sanctions.

These findings are entirely consistent with the idea that ILM mechanisms got their first push from federal labor legislation of the 1930s and 1940s (Jacoby 1985) and wartime labor market controls (Baron et al. 1986), both of which helped to designate ILM practices as solutions to problems of unionism, turnover, and motivation. Since 1964 federal EEO law has caused personnel managers to view formal selection and promotion practices as ways to protect employee rights and, simultaneously, rationalize the allocation of workers. One result is that management came to see affirmative action in a positive light - as a force for equity and efficiency (Harvard Law Review 1989). Legal changes also encouraged managers to treat all employees as career oriented and self-actualizing by creating organizational structures that would allow all classes of employees to pursue promotions, including groups employers previously took to have naturally low aspirations and weak needs for ego gratification (e.g., minorities and women).

It appears that legal changes have altered the meaning of ILM mechanisms since the 1960s (see Pfeffer and Cohen 1984); as a result, union attitudes have changed. Pfeffer and Cohen found strong evidence that, for personnel managers and unions, ILM mechanisms represent an effort to maximize management control. But since 1964, ILM practices have come to represent a means to achieve equity. Personnel managers continued to promote ILMs because it was in their interest to do so. And ILM mechanisms have continued to exemplify garbage-can theory's solutionin-search-of-a-problem, for EEO is just the latest in a series of problems personnel managers have sought to solve with ILMs (Cohen, March, and Olsen 1972). Yet the evidence suggests that once ILM mechanisms had taken on a different meaning, unions stopped opposing them. Our findings reinforce the idea that interest group goals are not primordial and unwavering; rather they change over time in response to shifts in the environment (DiMaggio 1988; Dobbin 1992).

We have suggested that organizational employment practices are driven by evolving conceptions of the individual, and of individual rights, that become institutionalized in public policy. Employment practices, in turn, feed back into these conceptions. To wit, ILM practices 
that make promotion available to all categories of employees portray ambition and achievement orientation as characteristics of all individuals-as inherent in individualism. These practices also democratize organizational representations of human motivation by breaking down the distinction between managers and employees Bendix (1956) identified in early thought and practice; in contemporary management doctrine even the lowest-level employees are driven by the same desire for mobility as their bosses. Of course, management practices designed to achieve efficiency have always been oriented to current ideas about human nature, and in turn they have always helped to construct beliefs about human nature. This was as true in the heyday of Taylorism as it is today. We view the legal and organizational concern with guarding the integrity of workers (e.g., sexual harassment policies), with participative management and work-group identification (e.g., quality circles), and with transforming all jobs into rungs on career ladders to make advancement available to all (e.g., open job bidding and formal promotion mechanisms) as integral to today's organizational representation of the individual. However, evidence that, since the mid-1980s, firms have moved away from long-term employment and toward short-term contracting suggests that the future of the organizational embodiments of individualism that we have depicted is uncertain (Hirsch 1991; Pfeffer and Baron 1988).

While prevailing rationalist theorists treat organizational structure as mainly responsive to economic imperatives that transcend time and locale, we have shown the impact of particular institutions found in the environment. Those institutions reflect and embody the expanding Western conception of the individual that is central to the project of modernity. Institutional attention to the individual has intensified and has produced new organizational practices in recent decades; this process has been fueled by pressures to achieve equity by extending the rights of occupational mobility and expanded organizational membership to all of society's members (Selznick 1969). The new organizational model for promoting equity incorporates practices that, at the same time, advance the project of rationalization by contributing to the efficient allocation of "human capital." Future studies could usefully set aside the premise that organizational practices are structured by extrasocietal principles of efficiency and attend to how the evolving institutional constructions of individualism and efficiency affect organizational practices.

\section{REFERENCES}

Abzug, Rikki, and Stephen Mezias. 1993. "The Fragmented State and Due Process Protections in Organizations: The Case of Comparable Worth." Organization Science 4:433-53. 
Ashenfelter, Orley, and James Heckmann. 1976. "Measuring the Effect of an Antidiscrimination Program." Pp. 46-84 in Evaluating the Labor-Market Effects of a Social Program, edited by Orley Ashenfelter and James Blum. Princeton, N.J.: Princeton University, Industrial Relations Section.

Baron, James N., Frank R. Dobbin, and P. Devereaux Jennings. 1986. "War and Peace: The Evolution of Modern Personnel Administration in U.S. Industry." American Journal of Sociology 92:350-83.

Bassford, Gerald L. 1974. "Job Testing-Alternative to Employment Quotas." Business Horizons 17:37-50.

Becker, Gary. 1971. The Economics of Discrimination, 2d ed. Chicago: University of Chicago Press.

Bell, Duran, Jr. 1971. "Bonuses, Quotas, and the Employment of Black Workers." Journal of Human Resources 6:309-20.

Bendix, Reinhard. 1956. Work and Authority in Industry. New York: Wiley.

Benokraitis, Nijole, and Joe Feagin. 1977. Affirmative Action and Equal Opportunity. Boulder, Colo.: Westview Press.

Blau, Peter M., Cecilia McHugh Falbe, William McKinley, and Phelps K. Tracy. 1976. "Technology and Organization in Manufacturing." Administrative Science Quarterly 21:20-40.

Blau, Peter M., and Richard A. Schoenherr. 1971. The Structure of Organizations. New York: Basic.

Brandes, Stuart D. 1976. American Welfare Capitalism, 1880-1940. Chicago: University of Chicago Press.

Burawoy, Michael. 1985. The Politics of Production. London: Verso.

Burstein, Paul. 1985. Discrimination, Jobs, and Politics: The Struggle for Equal Employment Opportunity in the United States since the New Deal. Chicago: University of Chicago Press.

- 1990. "Intergroup Conflict, Law, and the Concept of Labor Market Discrimination." Sociological Forum 5:459-76.

Burstein, Paul, and Kathleen Monaghan. 1986. "Equal Employment Opportunity and the Mobilization of Law." Law and Society Review 16:355-88.

Burstein, Paul, and Susan Pitchford. 1990. "Social-Scientific and Legal Challenges to Education and Test Requirements in Employment." Social Problems 37:243-57.

Campbell, Joel T. 1973. "Tests Are Valid for Minority Groups Too." Public Personnel Management 2:70-73.

Chayes, Antonia Handler. 1974. "Make Your Equal Opportunity Program CourtProof." Harvard Business Review 52:81-89.

Cohen, Michael D., James G. March, and Johan P. Olsen. 1972. "A Garbage Can Model of Organizational Choice." Administrative Science Quarterly 17:1-25.

Cohen, Yinon, and Jeffrey Pfeffer. 1986. "Organizational Hiring Standards." Administrative Science Quarterly 31:1-24.

Cole, Robert E. 1989. Strategies for Learning: Small-Group Activities in American, Japanese, and Swedish Industry. Berkeley and Los Angeles: University of California Press.

DiMaggio, Paul J. 1988. "Interest and Agency in Institutional Theory." Pp. 3-21 in Institutional Patterns and Organizations, edited by Lynne G. Zucker. Cambridge, Mass.: Ballinger.

DiMaggio, Paul J., and Walter W. Powell. 1983. "The Iron Cage Revisited: Institutional Isomorphism and Collective Rationality in Organizational Fields." American Sociological Review 35:147-60.

DiPrete, Thomas. 1989. The Bureaucratic Labor Market: The Case of the Federal Civil Service. New York: Plenum.

Dobbin, Frank. 1992. "The Origins of Private Social Insurance: Public Policy and 
Fringe Benefits in America, 1920-1950." American Journal of Sociology 97: 1416-50.

Dobbin, Frank, Lauren Edelman, John W. Meyer, W. Richard Scott, and Ann Swidler. 1988. "The Expansion of Due Process in Organizations." Pp. 71-100 in Institutional Patterns and Organizations: Culture and Environment. Cambridge, Mass.: Ballinger.

Doeringer, Peter B., and Michael J. Piore. 1971. Internal Labor Markets and Manpower Analysis. Lexington, Mass.: Heath.

Donohue, John J., III. 1986. "Is Title VII Efficient?" University of Pennsylvania Law Review 134:1411-31.

Dore, Ronald. 1973. British Factory_Japanese Factory. Berkeley: University of California Press.

Edelman, Lauren. 1990. "Legal Environments and Organizational Governance: The Expansion of Due Process in the American Workplace." American Journal of Sociology 95:1401-40.

- 1992. "Legal Ambiguity and Symbolic Structures: Organizational Mediation of Civil Rights Law." American Journal of Sociology 97:1531-76.

Edelman, Lauren B., Stephen Petterson, Elizabeth Chambliss, and Howard S. Erlanger. 1990. "Legal Ambiguity and the Politics of Compliance: Affirmative Action Officers' Dilemma." Manuscript. University of Wisconsin, Department of Sociology.

Edwards, Richard. 1979. Contested Terrain: The Transformation of the Workplace in the Twentieth Century. New York: Basic.

Farley, Jennie. 1979. Affirmative Action and the Woman Worker. New York: Amacom.

Fligstein, Neil. 1990. The Transformation of Corporate Control. Cambridge, Mass.: Harvard University Press.

Friedman, Milton. 1962. Capitalism and Freedom. Chicago: University of Chicago Press.

Gavin, James F., and David L. Toole. 1973. "Validity of Aptitude Tests for the 'Hardcore Unemployed.'” Personnel Psychology 26:139-46.

Giblin, Edward J., and Oscar Ornati. 1974. "A Total Approach to EEO Compliance." Personnel 51:32-43.

Gordon, David M., Richard Edwards, and Michael Reich. 1982. Segmented Work, Divided Workers. London: Cambridge University Press.

Gorham, William A. 1972. "New Answers on Employment Tests." Civil Service Journal 13:8-12.

Halle, David. 1984. America's Working Man. Chicago: University of Chicago.

Hamilton, Gary G., and John R. Sutton. 1989. "The Problem of Control in the Weak State: Domination in the United States, 1880-1920." Theory and Society 18:1-46.

Harvard Law Review. 1989. Note: "Rethinking Weber: The Business Response to Affirmative Action." Harvard Law Review 102:658-71.

Hirsch, Paul M. 1991. "Undoing the Managerial Revolution? Needed Research on the Decline of Middle Management and Internal Labor Markets." Paper presented at the annual meeting of the American Sociological Association, Cincinnati.

Jacoby, Sanford. 1984. "The Development of Internal Labor Markets in American Manufacturing Firms." Pp. 23-69 in Internal Labor Markets, edited by Paul Osterman. Cambridge, Mass.: MIT Press.

. 1985. Employing Bureaucracy: Managers, Unions, and the Transformation of Work in American Industry, 1900-1945. New York: Columbia University Press.

Kalleberg, Arne L., Peter V. Marsden, Howard E. Aldrich, and James W. Cassell. 1990. "Comparing Organizational Sampling Frames." Administrative Science Quarterly 35:658-88. 
Kochan, Thomas A., and Peter Cappelli. 1984. "The Transformation of the Industrial Relations and Personnel Function." Pp. 133-62 in Internal Labor Markets, edited by Paul Osterman. Cambridge, Mass.: MIT Press.

Leonard, Jonathan S. 1984a. "Antidiscrimination or Reverse Discrimination: The Impact of Changing Demographics, Title VII, and Affirmative Action on Productivity." Journal of Human Resources 19:145-74.

- 1984b. "The Impact of Affirmative Action on Employment." Journal of Labor Economics 2:439-63.

- 1985. "What Promises Are Worth: The Impact of Affirmative Action Goals." Journal of Human Resources 20:3-20.

Lincoln, James R., and Arne L. Kalleberg. 1985. "Work Organization and Workforce Commitment: A Study of Plants and Employees in the U.S. and Japan." American Sociological Review 50:738-60.

Lundberg, Shelly J. 1991. "The Enforcement of Equal Opportunity Laws under Imperfect Information: Affirmative Action and Alternatives." Quarterly Journal of Economics 106:309-26.

Maurice, Marc, A. Sorge, and M. Warner. 1980. "Societal Differences in Organizing Manufacturing Units: A Comparison of France, West Germany, and Great Britain." Organizational Studies 1:59-86.

Maurice, Marc, François Sellier, and Jean-Jacques Silvestre. 1984. "The Search for a Societal Effect in the Production of Company Hierarchy: A Comparison of France and Germany." Pp. 231-70 in Internal Labor Markets, edited by Paul Osterman. Cambridge, Mass.: MIT Press.

Meyer, John W., and Brian Rowan. 1977. "Institutionalized Organizations: Formal Structure as Myth and Ceremony." American Journal of Sociology 83:340-63.

Meyer, John W., and W. Richard Scott, eds. 1983. Organizational Environments: Ritual and Rationality. Beverly Hills, Calif.: Sage.

National Civil Service League. 1973. Training and Testing the Disadvantaged. Washington, D.C.: Consortium Press.

Peterson, Donald. 1974. "The Impact of Duke Power on Testing." Personnel 51: $30-37$.

Pfeffer, Jeffrey, and James N. Baron. 1988. "Taking the Workers Back Out: Recent Trends in the Structuring of Employment." Research in Organizational Behavior 10:257-303.

Pfeffer, Jeffrey, and Yinon Cohen. 1984. "Labor Markets in Organizations." Administrative Science Quarterly 29:550-72.

Phelps Brown, Henry. 1977. The Inequality of Pay. Oxford: Oxford University Press.

Pugh, D. S., D. J. Hickson, and C. R. Hinings. 1969. "An Empirical Taxonomy of Structures of Work Organizations." Administrative Science Quarterly 14:115-26.

Purcell, Theodore V. 1974. "How G.E. Measures Managers on Fair Employment." Harvard Business Review 52:99-104.

Scott, W. Richard. 1987. Organizations: Rational, Natural, and Open Systems, 2d ed. Englewood Cliffs, N.J.: Prentice-Hall.

Scott, W. Richard, and John W. Meyer. 1987. "Environmental Linkages and Organizational Complexity: Public and Private Schools." Pp. 128-60 in Comparing Public and Private Schools, edited by Henry M. Levin and Tom James. New York: Falmer.

Selznick, Philip. 1969. Law, Society, and Industrial Justice. New York: Russell Sage Foundation.

Slevin, Dennis. 1973. "Full Utilization of Women in Employment: The Problem and an Action Program." Human Resource Management 12:25-32.

Slichter, Sumner. 1919. The Turnover of Factory Labor. New York: Appleton.

Stark, David. 1986. "Rethinking Internal Labor Markets: New Insights from a Comparative Perspective." American Sociological Review 51:492-504. 
Sutton, John R., Frank Dobbin, John W. Meyer, and Richard Scott. 1994. "The Legalization of the Workplace." American Journal of Sociology 99 (January).

Taylor, Frederick. 1911. Scientific Management. New York: Harper.

Thomas, George, John Meyer, Francisco Ramirez, and John Boli. 1987. Institutional Structure: Constituting State, Society, and the Individual. Sage, Calif.: Beverly Hills.

Tolbert, Pamela, and Lynne G. Zucker. 1983. "Institutional Sources of Change in the Formal Structure of Organizations: The Diffusion of Civil Service Reforms, 1880-1935." Administrative Science Quarterly 23:22-39.

U.S. Equal Employment Opportunity Commission (EEOC). 1974. Affirmative Action and Equal Employment: A Guidebook for Employers, 2 vols. Washington, D.C.: EEOC.

Walsh, Richard J., and Lee R. Hess. 1974. "The Small Company, EEOC, and Test Validation Alternatives: Do You Know Your Options?" Personnel Journal 53:840-45.

Weber, Max. 1978. Economy and Society, vol. 2. Berkeley: University of California Press.

Whyte, William H., Jr. 1956. The Organization Man. New York: Simon \& Schuster. Williamson, Oliver. 1975. Markets and Hierarchies: Analysis and Antitrust Implications. New York: Free Press.

Zucker, Lynne G. 1983. "Organizations as Institutions." Pp. 1-47 in Research in the Sociology of Organizations, edited by Samuel B. Bacharach. Greenwich, Conn.: JAI Press. 